\title{
Effect of cold ischemic times and time after transplantation on regional myocardial motion after heart transplantation
}

Daniela Föll ${ }^{1 *}$, Michael Mark ${ }^{3,4}$, Marius Menza ${ }^{2}$, Asad Usman³ $^{3}$ Tobias Wengenmayer ${ }^{1}$, Anna Lena Anjarwalla ${ }^{1}$, Christoph Bode ${ }^{1}$, James Carr ${ }^{3}$, Bernd A Jung ${ }^{2}$

From 16th Annual SCMR Scientific Sessions

San Francisco, CA, USA. 31 January - 3 February 2013

\section{Background}

Transplant rejection affects the course and survival after heart transplantation (HTx). As a non-invasive alternative to myocardial biopsy, which is the gold standard used for screening and for the diagnosis of rejection, regional left ventricular (LV) myocardial motion analysis has been suggested. But myocardial biopsy is invasive and its diagnostic value is restricted by high sample errors due to the patchy distribution of early rejection. Alterations of regional wall motion [1], especially in diastole, might be sensitive for the diagnosis. However, evaluation by echocardiography is limited in this context and LV motion after HTx differs from the motion of native hearts. We assessed the influence of cold ischemic time (CIT) and time after HTx on myocardial velocities in stable HTx patients.

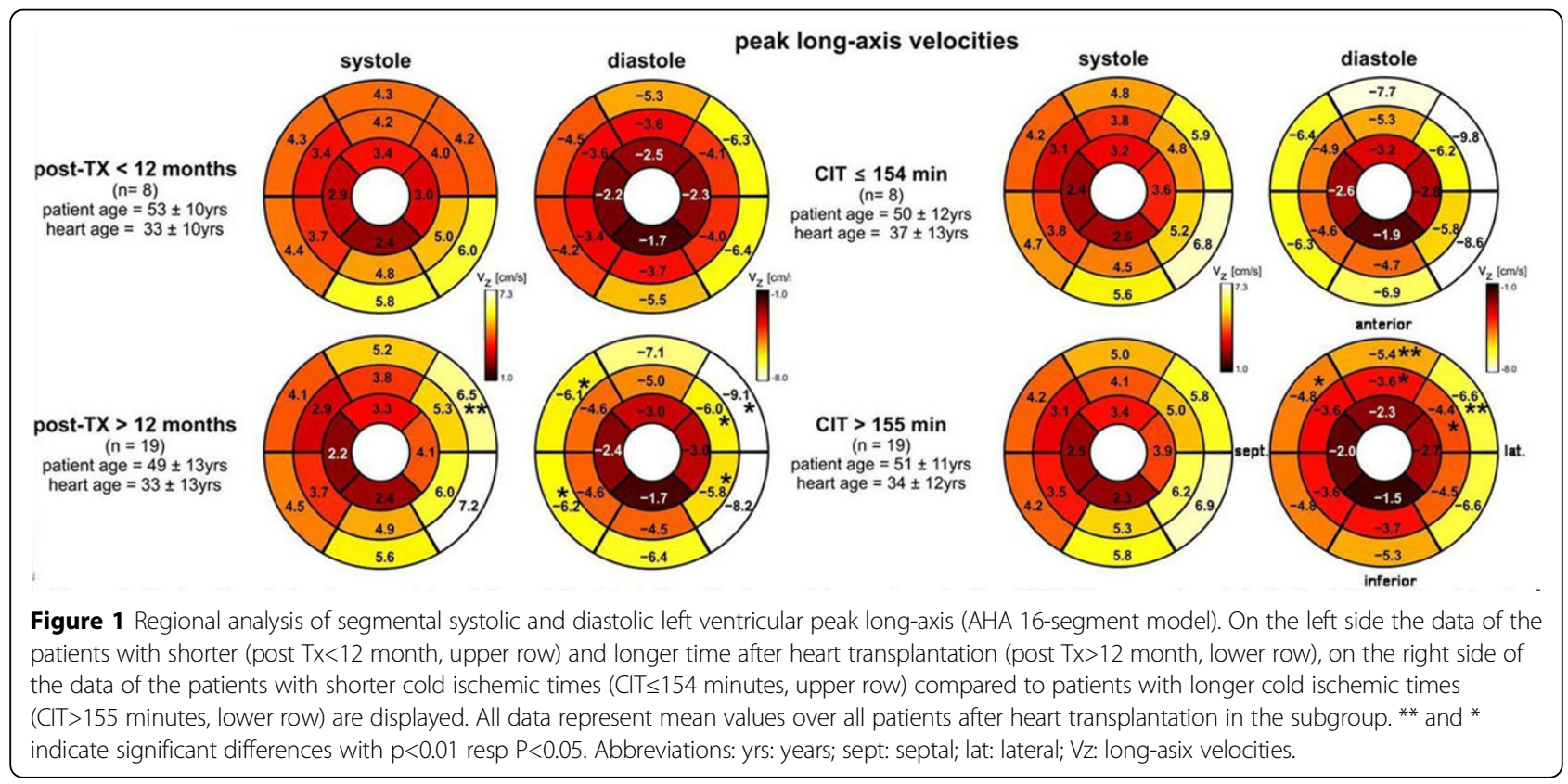

${ }^{1}$ Cardiology and Angiology I, University Heart Center Freiburg, Freiburg,

Germany

Full list of author information is available at the end of the article

\section{Biomed Central}

(c) 2013 Föll et al; licensee BioMed Central Ltd. This is an Open Access article distributed under the terms of the Creative Commons Attribution License (http://creativecommons.org/licenses/by/2.0), which permits unrestricted use, distribution, and reproduction in any medium, provided the original work is properly cited. 


\section{Methods}

27 heart transplant recipients $(50 \pm 13$ years, 6 female) without signs or former episodes of rejections or relevant transplant vasculopathy $(\mathrm{LVEF}=63 \pm 5 \%)$ were examined using phase contrast MRI (Tissue Phase Mapping) to assess 3D-myocardial velocities. Systolic and diastolic peak radial and long-axis velocities were evaluated in each LV segment. These functional parameters were analyzed with respect to time after HTx and CIT.

\section{Results}

Shorter times after HTx $(n=8$ patients $<12$ month after $H T x$ versus $n=19>12$ month) resulted in an increase of systolic radial velocities ( 2 of 16 segments, $\mathrm{p}=0.01-0.04$ ) and a reduction of diastolic long-axis velocities (5 of 16 segments, $\mathrm{p}=0.02-0.04)$. With longer CIT ( $>155$ minutes) an increase of peak systolic radial velocities $(\mathrm{p}=0.03-0.04$ for apico-septal and midventricular inferoseptal regions) and a reduction of diastolic long-axis velocities (5 of 16 segments, $\mathrm{p}=0.01-0.04$ ) were demonstrated compared to those with shorter CIT (<155 min) (see figure 1, results of long-axis velocities).

\section{Conclusions}

The transient suppression of long-axis velocities in the first months after HTx might be related to an early ischemia-reperfusion injury after cardiac surgery. The different behavior of long-axis and radial velocities with respect to time after HTx or CIT could be explained by the locations of the myocardial fibers underlying each motion component. Long-axis motion being mainly based on subendocardially located fibers might predispose this motion component for ischemic injury whereas circumferentially orientated fibers underlying radial motion are predominantly situated in the midmyocardium and might therefore have more functional reserves [2].

Time after HTx and CIT influence segmental systolic and diastolic velocities in stable patients after heart transplantation. These findings have to be considered if myocardial velocities are used as diagnostic tools in transplant rejection.

\section{Funding}

$\mathrm{NMH}$ Excellence in Academic Medicine (EAM) Program "Advanced Cardiovascular MRI Research Center”, Deutsche Forschungsgemeinschaft (DFG): Grant \# FO 507/2-1, FO 507/3-1.

\section{Author details}

${ }^{1}$ Cardiology and Angiology I, University Heart Center Freiburg, Freiburg, Germany. ${ }^{2}$ Department of Radiology, Medical Physics, University Hospital Freiburg, Freiburg, Germany. ${ }^{3}$ Department of Radiology, Feinberg School of Medicine, Northwestern University, Chicago, IL, USA. ${ }^{4}$ Department of
Biomedical Engineering, McCormick School of Engineering, Northwestern University, Chicago, IL, USA.

Published: 30 January 2013

\section{References}

1. Wu YL, et al:. JACC Cardiovasc Imaging 2009, 2(6):731-41.

2. Pauliks LB, et al:. J Heart Lung Transplant 2005, 24(11):1804-13.

doi:10.1186/1532-429X-15-S1-P99

Cite this article as: Föll et al:: Effect of cold ischemic times and time after transplantation on regional myocardial motion after heart transplantation. Journal of Cardiovascular Magnetic Resonance 2013 15(Suppl 1):P99.
Submit your next manuscript to BioMed Central and take full advantage of:

- Convenient online submission

- Thorough peer review

- No space constraints or color figure charges

- Immediate publication on acceptance

- Inclusion in PubMed, CAS, Scopus and Google Scholar

- Research which is freely available for redistribution

Submit your manuscript at www.biomedcentral.com/submit 